\title{
Spatial and temporal variability of prokaryotes, viruses, and viral infections of prokaryotes in an alkaline, hypersaline lake
}

\author{
Jennifer R. Brum ${ }^{1, *}$, Grieg F. Steward ${ }^{1}$, Sunny C. Jiang $^{2}$, Robert Jellison ${ }^{3}$ \\ ${ }^{1}$ Department of Oceanography, University of Hawaii at Manoa, Honolulu, Hawaii 96822, USA \\ ${ }^{2}$ Environmental Health, Science and Policy, University of California, Irvine, California 92696, USA \\ ${ }^{3}$ Marine Science Institute, University of California, Santa Barbara, California 93106, USA
}

\begin{abstract}
Mono Lake is a large, alkaline, moderately hypersaline lake containing planktonic prokaryotes and viruses at concentrations that are among the highest reported for natural aquatic environments. We hypothesized that pronounced seasonality in physical and biological forcing and strong vertical gradients of chemical, physical, and biological parameters in this meromictic lake would result in dramatic temporal and spatial variability in concentrations of viruses and viral infections of prokaryotes. To test this, we investigated the temporal, vertical, and horizontal variability in hydrography, microbial concentrations, and viral infections of prokaryotes at 4 stations over a 10 mo period in Mono Lake. The infection parameters quantified included the frequency of visibly infected cells (FVIC), burst size, intracellular virus diameter, and volume of infected cells. Concentrations of chlorophyll a (chl a), prokaryotes, and viruses in individual samples ranged from 3.3 to $150 \mu \mathrm{g} \mathrm{l}^{-1}$, 0.10 to $1.2 \times 10^{11} \mathrm{l}^{-1}$, and 0.14 to $1.9 \times 10^{12} \mathrm{l}^{-1}$, respectively, with the highest concentrations of each occurring in the spring. For all data combined, concentrations of viruses were significantly correlated with concentrations of prokaryotes $(\mathrm{r}=0.68, \mathrm{p}<0.001, \mathrm{n}=68)$, but not with chl $a$. FVIC ranged from $<0.1$ to $3.5 \%$ for the community, but reached as high as $13 \%$ for coccoid cells in 1 sample. Averaged over the water column, the estimated fraction of prokaryote mortality due to viral lysis ranged from a low of $3.7 \%$ in September, to a high of $16 \%$ in July. Burst size, intracellular virus diameters, and volumes of infected cells were temporally variable with a trend of decreasing burst size through the spring and summer as a result of larger viruses infecting smaller cells. In contrast, these parameters did not differ systematically among stations or between the anoxic and oxic layers of the lake. The data suggested that seasonal forcing is the primary source of variability in viral infections in the lake. Overall, viral lysis appeared to make a modest contribution to the mortality of prokaryotes, but high virus-host contact rates suggested that viruses are likely to influence the clonal diversity of picoplankton in the lake.
\end{abstract}

KEY WORDS: Prokaryotes $\cdot$ Viruses $\cdot$ Hypersaline lake $\cdot$ Variability Resale or republication not permitted without written consent of the publisher

\section{INTRODUCTION}

Mono Lake is a large $\left(180 \mathrm{~km}^{2}\right)$, temperate, alkaline ( $\mathrm{pH} \sim 10$ ), moderately hypersaline (70 to $85 \mathrm{~g} \mathrm{~kg}^{-1}$ ) lake with an average depth of $17 \mathrm{~m}$, located in the eastern part of the Sierra range in California at an elevation of ca. $1950 \mathrm{~m}$. The concentrations of viruses and prokaryotes in this unusual lake are among the highest reported for a natural aquatic ecosystem (Jiang et al. 2004), but the impact of viruses on the lake's prokaryotic plankton com- munity has not been previously investigated. Food web models (Fuhrman \& Suttle 1993, Murray \& Eldridge 1994) and experimental data (Middelboe et al. 1996) suggest that, by converting cellular biomass to dissolved organic carbon, viral lysis can stimulate microbial growth and respiration with a concomitant decrease in the transfer of carbon to higher trophic levels via grazing. Since one of the first-order controls on the spread of infections is the rate of contact between viruses and host cells (Murray \& Eldridge 1994, Wilcox \& Fuhrman 1994), 
it has been hypothesized that the exceptionally high concentrations of viruses and prokaryotes in Mono Lake would be accompanied by a high incidence of infection (Jiang et al. 2004). If true, then viruses could have a substantial effect on the flow of carbon in the lake.

Estimates of viral infection rates have been made for a variety of aquatic environments including freshwater, seawater, and hypersaline ponds; however, mechanisms controlling the frequency of viral infection are not always clear. While general associations have been observed between infection rates and indicators of trophic status, including microbial concentrations and growth rates (Weinbauer et al. 1993, Guixa-Boixareu et al. 1996, Steward et al. 1996, Bettarel et al. 2004), these correlations are not always consistent among studies. This suggests that multiple, interacting factors regulate the frequency of infection, and that these factors may vary among ecosystems. Mono Lake has a complex combination of vertical and seasonal variability in physical, chemical, and biological parameters that make it an attractive system in which to investigate some of the factors that affect variability in viral abundance and frequency of viral infections.

While Mono Lake has historically had a monomictic annual mixing regime, 2 periods of persistent stratification (1983 to 1988, and 1995 to 2003) have resulted from high freshwater input and changes in water diversion policies (Jellison \& Melack 1993a, Jellison et al. 1998). These periods of meromixis resulted in persistent anoxia and high concentrations of ammonia and sulfide in the monimolimnion, as well as enhanced primary productivity due to the upward fluxes of nutrients (Jellison \& Melack 1993b). Previous studies have shown that concentrations and diversity of viruses and prokaryotes differ between the oxic and anoxic layers of Mono Lake (Hollibaugh et al. 2001, Humayoun et al. 2003, Jiang et al. 2004). These observations, along with reports of dramatic differences in the rate of viral infections between the oxic and anoxic layers in other stratified lakes (Weinbauer \& Hofle 1998a, Bettarel et al. 2004), suggest that the frequency of viral infections are likely to differ significantly between the surface and deep waters of Mono Lake.

Mono Lake also displays strong seasonal variability including an annual spring phytoplankton bloom that is grazed by the brine shrimp Artemia monica in the mixolimnion from late spring through summer (Lenz et al. 1986, Jellison \& Melack 1988). Artemia monica are not generally found in the anoxic waters (Lenz et al. 1986), which allows the unicellular alga Picocystis sp. strain ML (Roesler et al. 2002) — capable of growth under anoxic or oxic conditions - to persist in the monimolimnion during the summer. Decline of $A$. monica at the end of summer is then followed by a fall bloom of phytoplankton (Melack \& Jellison 1998). The lake is also variable on longer time scales with transitions from monomixis to meromixis. The breakdown of meromixis redistributes ammonia from the monimolimnion throughout the water column (Jellison \& Melack 1993a), resulting in a stimulation of primary productivity (Jellison \& Melack 1993b). This seasonal and interannual variability of phytoplankton biomass is hypothesized to affect the dynamics of viral infection in Mono Lake, because concentrations of viruses and bacteria have been found to vary temporally during phytoplankton blooms in other ecosystems; this is presumably due to fluctuations in nutrients, dissolved organic matter (DOM), and dead phytoplankton associated with the blooms (Bratbak et al. 1990, Rodriguez et al. 2000).

The study of viral ecology in Mono Lake is also of interest because there are relatively few data from hypersaline environments. Although viral abundance is sometimes negatively correlated with salinity in coastal waters (Paul et al. 1993, Weinbauer et al. 1993), salinity per se cannot be considered a limiting factor on steady state viral concentrations. Higher concentrations of viruses have been found in saline lakes relative to freshwater lakes in Antarctica (Laybourn-Parry et al. 2001), and the concentration of viruses in Mono Lake (Jiang et al. 2004) and salt evaporator ponds (Guixa-Boixareu et al. 1996) are among the highest reported for any aquatic environment. Virus and prokaryote concentrations were, in fact, found to increase with salinity in the salterns, although there was not a consistent increase in the frequency of viral infection (Guixa-Boixareu et al. 1996). The unusual features of Mono Lake make it unclear whether one should expect the viral ecology and patterns of viral infection there to bear any similarity to other ecosystems with which the lake shares some characteristics, such as meromictic freshwater lakes (Weinbauer \& Hofle 1998a, Bettarel et al. 2004) or hypersaline evaporator ponds (Guixa-Boixareu et al. 1996).

This study reports on the spatial (horizontal and vertical) variability and seasonal dynamics of viruses, prokaryotes, and phytoplankton biomass in Mono Lake over a 10 mo period including the breakdown of meromixis. Variability in the frequency of viral infections was also investigated and compared between the oxic and anoxic zones of the lake, and electron microscopic quantification of infected cell morphotypes, cell volume, and intracellular virus diameters were used to investigate sources of variability in burst size.

\section{MATERIALS AND METHODS}

Sampling sites and sample collection. Three pelagic stations (Stns 2, 6, and 7) and 1 nearshore station (Stn 11) in Mono Lake (Fig. 1) were sampled at approximately monthly intervals between March and 

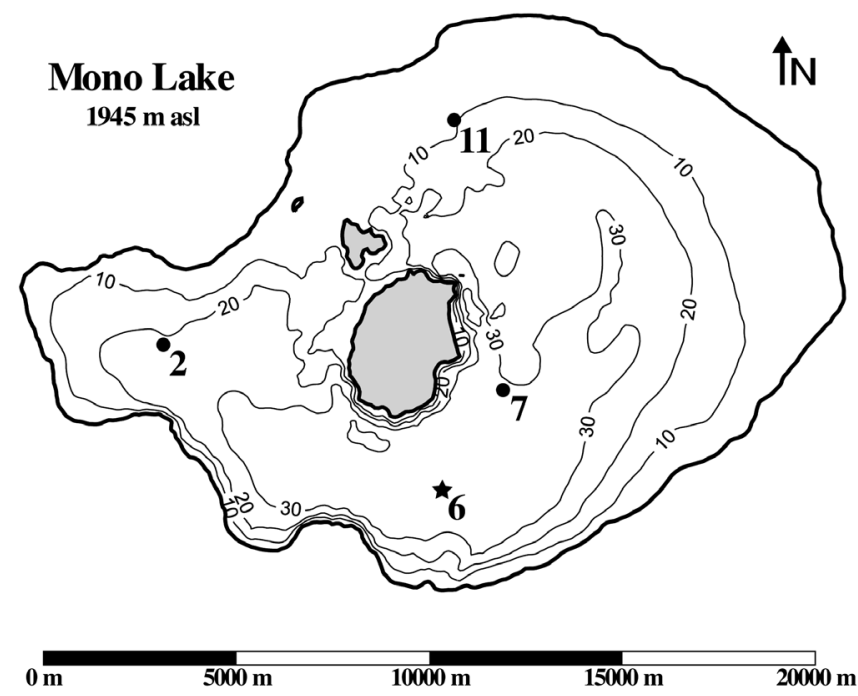

Fig. 1. Mono Lake and stations sampled. Depth profiles were collected at Stn $6(\star)$, and 0-9 $\mathrm{m}$ integrated samples were collected from Stns 2, 6, 7, and 11; $10 \mathrm{~m}$ depth contours are indicated

December, 2003. Samples were collected each month at Stn 6 from a depth profile of 8 to 9 depths, ranging from 2 to $35 \mathrm{~m}$, using a Niskin bottle. To assess horizontal variability, 0-9 $\mathrm{m}$ integrated samples were collected at Stns 2, 6, 7, and 11 using a $2.5 \mathrm{~cm}$ diameter tube. The concentrations of prokaryotes and viruses were determined in depth profiles from Stn 6 and 0-9 m integrated samples from all 4 stations from April to December, with the exception of September. Samples for the determination of frequency of visibly infected cells (FVIC) and other data from infected cells were collected from the depth profile at Stn 6 from March to December, with the exception of April and November. The 0-9 m integrated samples were collected from all 4 stations in May, July, August, and December. Depth profiles of water temperature, dissolved oxygen, and chl a concentrations were measured at Stn 6 at monthly to bimonthly intervals between March and December.

Temperature, dissolved oxygen, and chl a. Water temperature was measured with a conductivitytemperature-depth profiler (CTD; Seabird Electronics model SEACAT 19). Dissolved oxygen was measured with a Clarke-type polarographic electrode (Yellow Springs Instruments model 5739) calibrated against Miller titrations (Walker et al. 1970), using water from Mono Lake. Chl a concentrations were determined via acetone extraction and spectrophotometric or fluorescence measurements as previously described (Jellison $\&$ Melack 2001).

Concentrations of prokaryotes and viruses. Water samples were fixed with $0.02 \mu \mathrm{m}$ filtered formaldehyde (final concentration $1 \%$ ) immediately upon col- lection. Prokaryotes and viruses were enumerated by epifluorescence microscopy using a SYBR Green I staining method (Noble \& Fuhrman 1998). Slides for enumeration of prokaryotes and viruses were prepared within $24 \mathrm{~h}$ of sample collection, and were either counted immediately after preparation or stored at $-20^{\circ} \mathrm{C}$ before being counted under blue excitation on an Olympus BX60 microscope using an Olympus MicroSuite-B3 software system (Soft Imaging System) for image capture and counting. At least 1500 particles of viruses and 200 particles of prokaryotes were counted from 5 to 10 randomly selected fields per filter.

Contact rates between prokaryotes and viruses were estimated as $\left(S h \times 2 \pi \times d \times D_{\mathrm{v}}\right) V P$ as described previously (Murray \& Jackson 1992), where Sh is the Sherwood number for bacteria (1.01), $d$ is the diameter of prokaryotes, $D_{\mathrm{v}}$ is the diffusivity of viruses $\left(3 \times 10^{-3}\right.$ $\mathrm{cm}^{2} \mathrm{~d}^{-1}$ ) assuming an average virus diameter of $82 \mathrm{~nm}$ for Mono Lake (authors' unpubl. data), $V$ is the concentration of viruses, and $P$ is the concentration of prokaryotes. Contact rates were calculated for each depth sampled in vertical profiles at Stn 6. Dimensions were only available for infected cells, so the monthly water column average equivalent spherical diameter of infected cells was used for all calculations of contact rates in a given month. Specific contact rates were then calculated by dividing contact rates by the concentrations of prokaryotes resulting in the number of contacts cell $^{-1} \mathrm{~d}^{-1}$.

FVIC, burst size, virus diameter, and cell volume. Samples were preserved with $0.22 \mu \mathrm{m}$ filtered formaldehyde (final concentration $2 \%$ ) and refrigerated until grid preparation. Samples $(500 \mu \mathrm{l})$ were centrifuged for $15 \mathrm{~min}$ at $15000 \times g$ with a swing-bucket rotor to deposit cells onto 200-mesh copper grids coated with carbon-stabilized formvar which had been rendered hydrophilic by UV irradiation $(240 \mathrm{~mJ})$ immediately prior to use. Deposited material was stained by immersing the grids in fresh $0.5 \%$ uranyl acetate for $30 \mathrm{~s}$ followed by $3 \times 10 \mathrm{~s}$ rinses in purified water (NANOPure DIamond). Excess liquid was wicked away from the grids, and they were stored desiccated until analysis.

For each grid, 800 cells were examined at $40000 \times$ magnification using a transmission electron microscope (LEO 912) with $100 \mathrm{kV}$ accelerating voltage. Cells were scored as visibly infected if they contained 5 or more mature viruses, and the morphotype of each cell was subjectively recorded as a thin rod, fat rod, coccus, or spirillum based on observations of the cell population. Transmission electron micrographs were taken of each visibly infected cell (VIC) with a Proscan Slow-Scan Frame-Transfer cooled CCD camera with $1 \mathrm{~K} \times 1 \mathrm{~K}$ resolution run with analySIS (Soft Imaging Systems) software. Burst sizes were estimated by 
counting viruses within cells that appeared to be full of viruses. The length and width of each VIC, and the diameter of viruses within each VIC (intracellular viruses), were measured with Image-Pro Plus software (Media Cybernetics). The volumes of cells were calculated assuming that the true shapes of cells could be approximated as spheres or as cylinders with hemispherical ends. The FVIC was calculated for each sample as the percentage of total cells that were visibly infected with viruses. The fraction of mortality from viral lysis (FMVL) for cells in each sample was then calculated from FVIC using the model equations derived by Binder (1999), with the assumptions that viral latent period equals bacterial generation time and that the fraction of the latent period during which viral particles are visible is 0.186 (Proctor et al. 1993).

Statistical analyses. All Pearson correlation analyses, $t$-tests, ANOVAs, and Tukey tests were performed with Minitab student release 12. Tukey tests were performed for all comparisons if the results of the ANOVA showed significant differences among samples. An alpha value of 0.05 was used to determine significance for all tests. All errors of calculated means were reported as mean $\pm 1 \mathrm{SD}$. The FVIC and FMVL were reported to 2 significant digits or to 1 decimal place, whichever was less. Contact rates were reported to 1 significant digit due to the large uncertainties resulting from using mean community values in the calculation.

\section{RESULTS}

\section{Seasonal hydrography and chl a concentrations}

Mono Lake was chemically stratified throughout the sampling period until November, when continued evaporative concentration of waters in the mixed layer and autumnal cooling led to holomixis. Seasonal thermal stratification was pronounced with near-surface temperature ranging from 5 and $6^{\circ} \mathrm{C}$ in March and December, to $\sim 20^{\circ} \mathrm{C}$ in June through to August (Fig. 2A). Temperature in the monimolimnion ranged from 3 to $8^{\circ} \mathrm{C}$ until holomixis in November, when water temperatures ranged from 8 to $10^{\circ} \mathrm{C}$ throughout the water column. Further cooling and mixing led to isothermal conditions at approximately $5.6^{\circ} \mathrm{C}$ by midDecember.

The concentration of dissolved oxygen in the mixolimnion ranged from 3.8 to $9.4 \mathrm{mg} \mathrm{l}^{-1}$, and the monimolimnion remained anoxic until the lake turned over in November (Fig. 2B). The overturn resulted in anoxic conditions below $2 \mathrm{~m}$ due to the oxidation of reduced chemical species from the monimolimnion that were mixed throughout the water column. In December, the entire water column was oxygenated, but with low concentrations of dissolved oxygen ranging from 1.7 to $2.8 \mathrm{mg} \mathrm{l}^{-1}$.

Chl a ranged from 48 to $88 \mu \mathrm{g} \mathrm{l}^{-1}$ in the mixolimnion during the spring phytoplankton bloom in April to May (Fig. 2C). The concentration then decreased to a minimum of $3.3 \mathrm{\mu g} \mathrm{l}^{-1}$ in the mixolimnion from June to September, but remained high in the monimolimnion with concentrations ranging from 40 to $150 \mathrm{\mu g} \mathrm{l}^{-1}$; the latter value was the seasonal maximum that occurred in June in a narrow band just below the oxycline. $\mathrm{Chl} \mathrm{a}$ concentrations then increased in the mixolimnion between September and October, and ranged from 29 to $62 \mu \mathrm{g} \mathrm{l}^{-1}$ through to December with a slight increase in November when the lake turned over.

\section{Concentration of prokaryotes and viruses}

The concentration of prokaryotes in depth profiles at Stn 6 ranged from $1.0 \times 10^{10} \mathrm{l}^{-1}$ (20 m in July) to $1.2 \times$ $10^{11} \mathrm{l}^{-1}(24 \mathrm{~m}$ in June; Fig. 2D), with an average of $4.4 \pm$ $2.7 \times 10^{10} \mathrm{l}^{-1}$ for all samples. Viral concentrations ranged from $1.4 \times 10^{11} \mathrm{l}^{-1}$ (24 $\mathrm{m}$ in October) to $1.9 \times 10^{12}$ $\mathrm{I}^{-1}$ (28 $\mathrm{m}$ in May; Fig. 2e), with an average of $7.4 \pm 4.1 \times$ $10^{11} \mathrm{l}^{-1}$ for all samples. The virus:prokaryote ratio (VPR) ranged from 5.8 (12 $\mathrm{m}$ in April) to 47.0 (20 m in July), with an average of $19 \pm 9$ for the study period. Concentrations of prokaryotes and viruses were highest throughout the water column from April to June. Prokaryotic and viral concentrations peaked again in November, coinciding with the overturn of the lake and occurring 1 mo after the autumn increase in chl a in the mixolimnion. There were no significant differences in VPR or concentrations of prokaryotes and viruses between the oxic and anoxic zones of the water column for the entire data set or for any individual vertical profile.

The estimated water-column average contact rates between prokaryotes and viruses ranged from $3 \times 10^{12}$ contacts $\mathrm{l}^{-1} \mathrm{~d}^{-1}$ in October to $2 \times 10^{14}$ contacts $\mathrm{l}^{-1} \mathrm{~d}^{-1}$ in April. These rates translated into specific contact rates ranging from $2 \times 10^{2}$ to $2 \times 10^{3}$ cell $^{-1} \mathrm{~d}^{-1}$.

\section{FVIC}

Regarding depth profile data from Stn 6, the maximum FVIC was $3.5 \%$ at $11.5 \mathrm{~m}$ in July and was below detection limit $(<0.1 \%)$ in only 4 of 69 samples (20 $\mathrm{m}$ in May, $16 \mathrm{~m}$ in June, $28 \mathrm{~m}$ in August, and $16 \mathrm{~m}$ in October). The average FVIC for the study period was $0.8 \pm 0.7 \%$. Because FVIC was highly erratic among samples in vertical profiles, the data were analyzed as averages of samples from the entire 


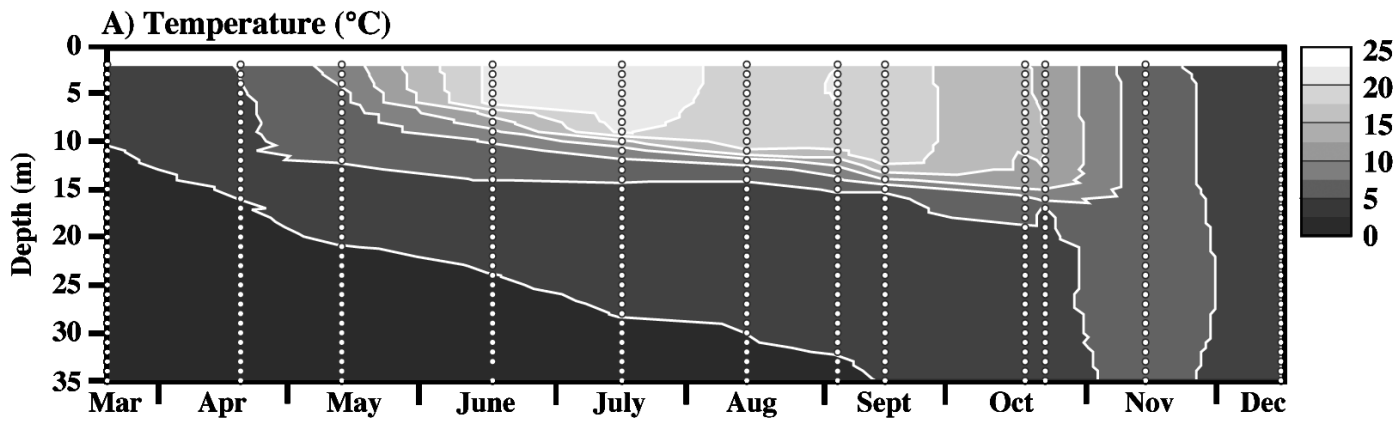

B) Oxygen ( $\left.\mathrm{mg} \mathrm{l}^{-1}\right)$

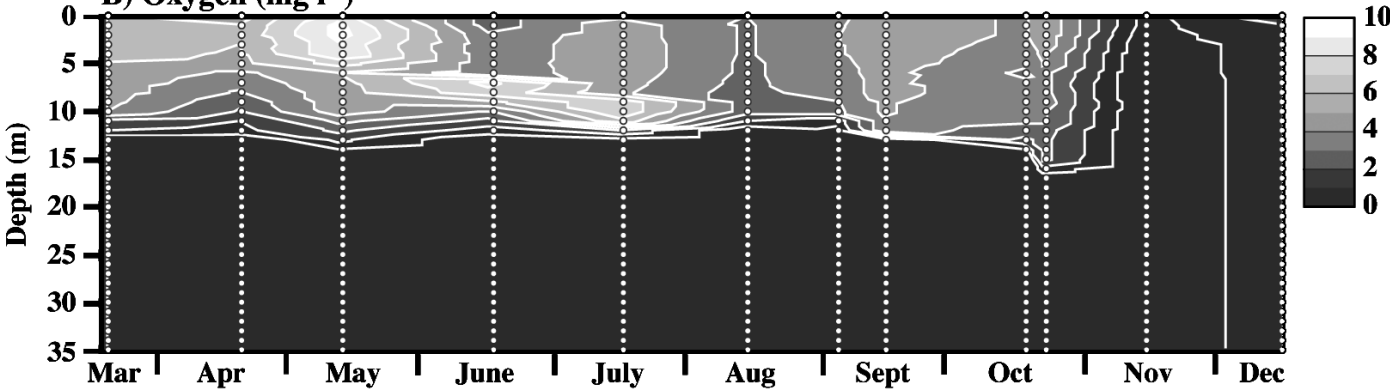

C) Chlorophyll $a\left(\mu \mathrm{g} \mathrm{l}^{-1}\right)$

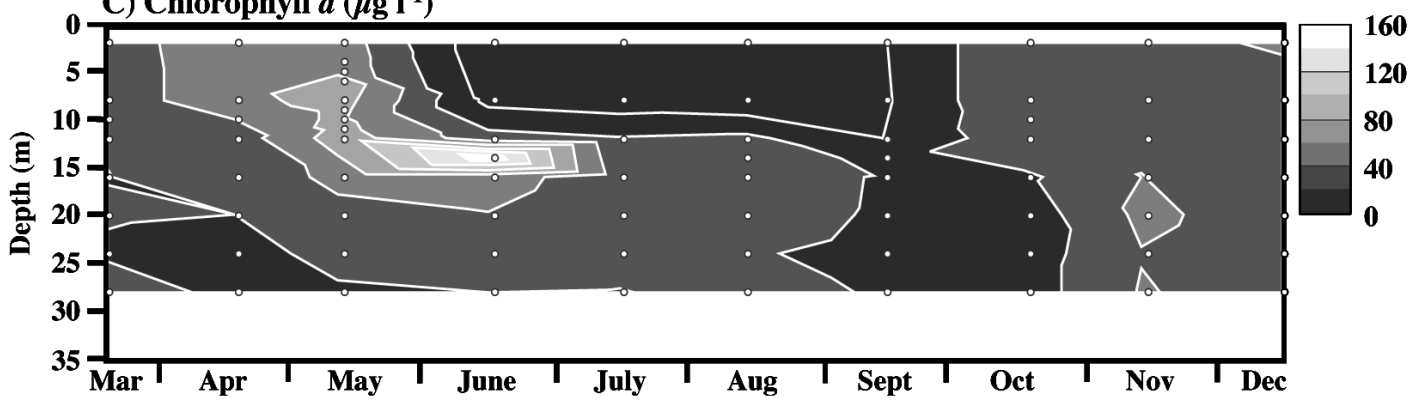

D) Prokaryotes $\left(\mathbf{x ~ 1 0}^{10} \mathrm{I}^{-1}\right)$

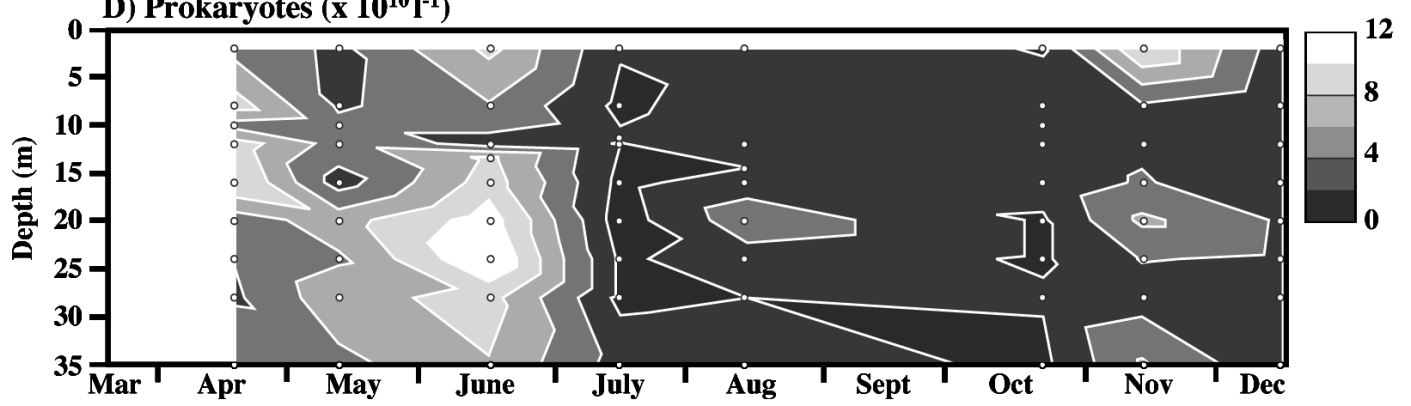

E) Viruses $\left(\mathbf{x ~ 1 0}^{11} \mathbf{l}^{-1}\right)$

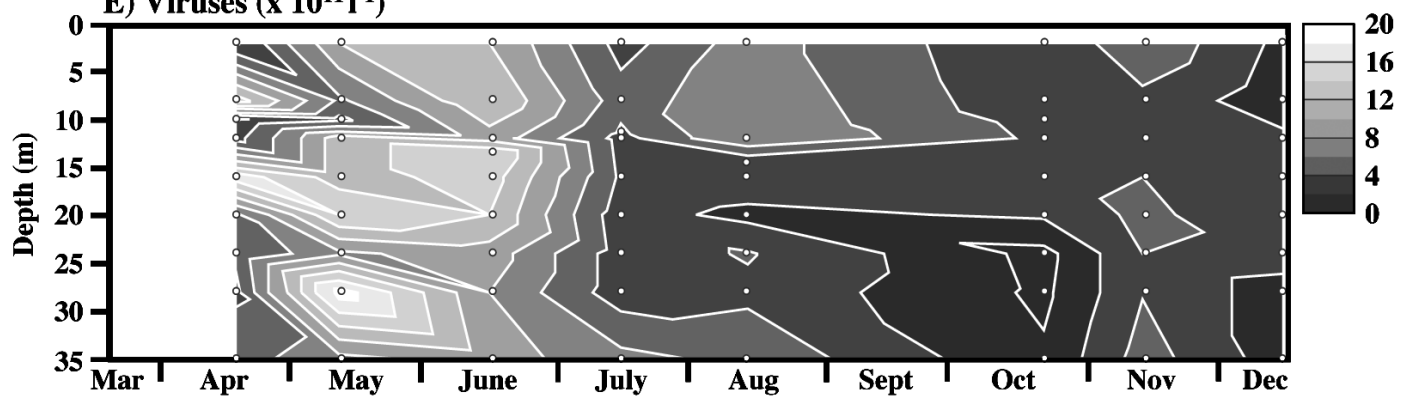

Fig. 2. Time series contours of (A) temperature, (B) dissolved oxygen, (C) concentration of chl $a_{r}$ (D) concentration of prokaryotes, and (E) concentration of viruses in depth profiles at Stn 6. Circles correspond to depths and dates of sample collection 


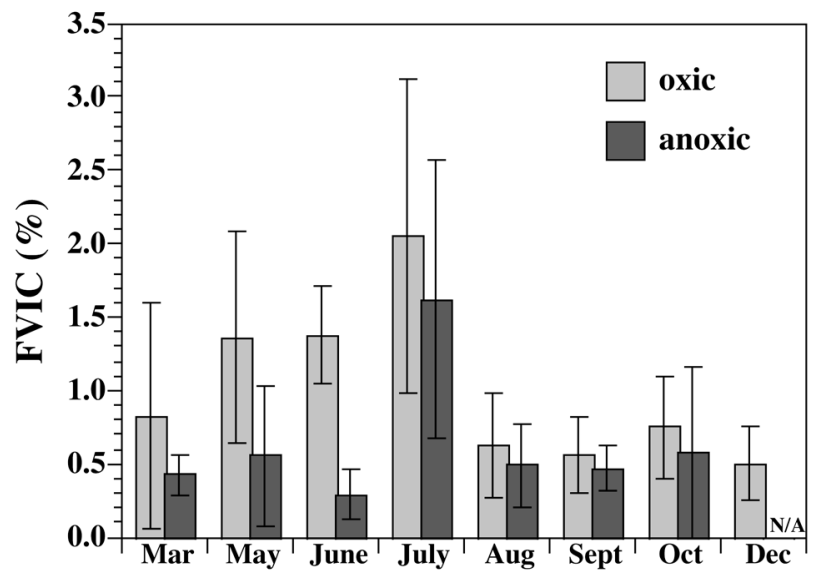

Fig. 3. Mean frequency of visibly infected cells (FVIC) in samples collected from the oxic and anoxic zones of depth profiles at Stn 6 for each month sampled. Error bars $=1 \mathrm{SD}$. No data available for the anoxic zone in December: the entire water column was oxygenated

water column or as separate averages for the oxic and anoxic zones for each month. The water column average FVIC increased between March and July, then decreased in August and remained relatively low through to December (Fig. 3). July had significantly higher FVIC than any other month (ANOVA, p < 0.001), and was also the month in which concentrations of prokaryotes and viruses had decreased throughout the water column. For all months combined, FVIC was significantly higher in the oxic zone than in the anoxic zone $(t$-test, $\mathrm{p}=$ 0.047); however, when data from individual months were tested, this difference was only significant for June ( $t$-test, $\mathrm{p}=0.033$ ). There was also never an apparent maximum or minimum in FVIC at the oxycline in any vertical profile.

The water column average FMVL estimated from FVIC ranged from $3.7 \pm 1.4 \%$ in September to $16 \pm$ $10 \%$ in July, with an average of $6.3 \pm 6.2 \%$ over the study period (Table 1). Estimated FMVL in the oxic zone ranged from $3.8 \pm 2.0 \%$ in December to $18 \pm$ $11 \%$ in July; in the anoxic zone, estimated FMVL ranged from $3.2 \pm 1.1 \%$ in March to $14 \pm 9 \%$ in July.

\section{Variability among stations}

When data from the $0-9 \mathrm{~m}$ integrated samples at each of the 4 stations were averaged, overall temporal trends in concentrations of prokaryotes and viruses in surface waters were illustrated: higher concentrations were observed from April to June, followed by a decrease in concentrations from July onwards (Fig. 4a). The coefficient of variation of viral concentrations
Table 1. Monthly means of the fraction of mortality from viral lysis (FMVL) from depth profiles at Stn 6. na: not applicable; there was no anoxic zone in the water column in December

\begin{tabular}{|lrcr|}
\hline \multirow{2}{*}{ Month } & \multicolumn{3}{c|}{ FMVL $(\%)$} \\
\cline { 2 - 4 } & Water column & Oxic & Anoxic \\
\hline March & $4.7 \pm 4.5$ & $6.7 \pm 6.6$ & $3.2 \pm 1.1$ \\
May & $7.4 \pm 6.1$ & $11.2 \pm 6.5$ & $4.3 \pm 3.9$ \\
June & $5.2 \pm 4.8$ & $11.2 \pm 3.0$ & $2.1 \pm 1.3$ \\
July & $15.9 \pm 9.8$ & $18.3 \pm 11.2$ & $13.9 \pm 9.2$ \\
August & $3.9 \pm 2.2$ & $4.7 \pm 2.8$ & $3.7 \pm 2.2$ \\
September & $3.7 \pm 1.4$ & $4.2 \pm 2.1$ & $3.5 \pm 1.2$ \\
October & $5.2 \pm 3.7$ & $5.8 \pm 2.8$ & $4.5 \pm 4.7$ \\
December & $3.8 \pm 2.0$ & $3.8 \pm 2.0$ & na \\
& & & \\
\hline
\end{tabular}

among stations ranged from 11 to $51 \%$, with the highest variability occurring in June and the lowest in April. The variability of prokaryotic concentrations among stations was similar to that of viruses, with coefficients of variation ranging from $3 \%$ in December to $48 \%$ in October. FVIC in the 0-9 m integrated samples from all stations (Fig. 4B) exhibited a similar temporal trend to that in vertical profiles from Stn 6: FVIC increased from May to July, followed by a decrease in August and December. The coefficient of variation in FVIC among
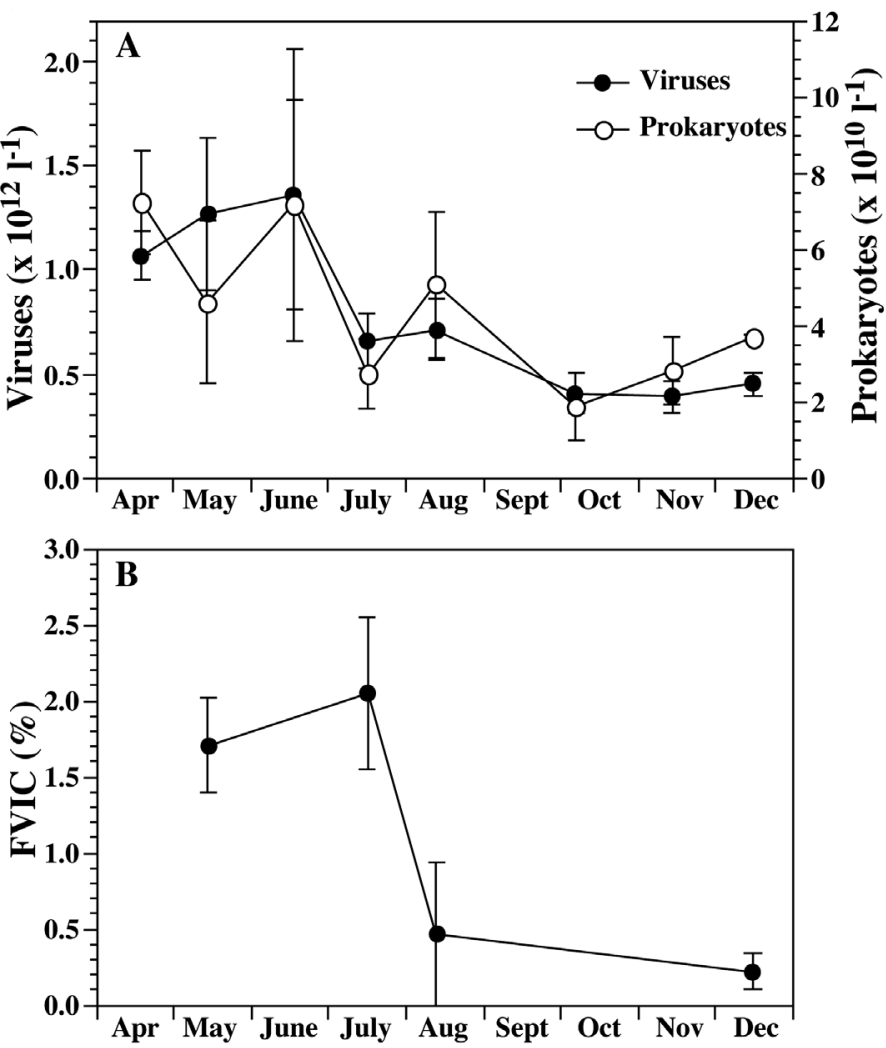

Fig. 4. Mean concentrations of (A) prokaryotes and viruses and (B) FVIC in 0-9 m integrated samples collected from Stns

$2,6,7$, and 11 for each date sampled. Error bars $=1 \mathrm{SD}$ 
stations ranged from $18 \%$ in May to $101 \%$ in August. No station consistently had the highest or lowest FVIC or concentration of viruses or prokaryotes.

\section{Burst size, virus diameter, and cell volume}

Estimates of burst size ranged from 10 to 560 viruses cell $^{-1}$, with an average of $100 \pm 90$ viruses cell ${ }^{-1}$ ( $\mathrm{n}=$ 102) for all cells. Burst sizes tended to decrease from March through July, then increased in August and varied only slightly until December, when the maximum average burst size occurred (Fig. 5A). Burst sizes in December were significantly higher than in May, June, July, and October (ANOVA, p = 0.002), but there were no other significant differences among months.

The diameters of intracellular viruses ranged from 16 to $110 \mathrm{~nm}$, with an average of $40 \pm 15 \mathrm{~nm}(\mathrm{n}=330)$ for the study period. There was a tendency for intracellular virus diameters to increase from March through July, followed by a decrease in diameter in August (Fig. 5B); however, differences among months were not considered significant based on ANOVA.

The volume of VIC ranged from 0.006 to $0.75 \mu^{3}$, with an average of $0.08 \pm 0.1 \mu^{3}$. Volumes of VIC decreased from March to July, increased in August, and then varied only slightly until December when they decreased again (Fig. 5C). Volumes of VIC were significantly lower in June and July than in March (ANOVA, p = 0.035), but there were no other significant differences between any 2 months.

Burst sizes were not significantly different between the oxic and anoxic zones for all months combined, and the only significant difference in individual months was in August when burst sizes were significantly larger in the anoxic zone ( $t$-test, $\mathrm{p}=0.012)$. There was also no significant difference in the diameters of intracellular viruses between the oxic and anoxic zones for all months combined; however, in individual months, the diameters of intracellular viruses were significantly larger in the anoxic zone in August ( $t$-test, $\mathrm{p}=0.002$ ), and significantly larger in the oxic zone in October ( $t$-test, $\mathrm{p}=0.043)$. The volumes of VIC were significantly larger in the anoxic zone for all months combined ( $t$-test, $\mathrm{p}=0.016$ ), but in individual months the volumes of VIC were only significantly larger in the anoxic zone in August ( $t$-test, p < 0.001).

\section{Correlations}

Concentrations of viruses and prokaryotes were correlated among all depth profile data from Stn 6 ( $\mathrm{r}=$ $0.68, \mathrm{p}<0.001, \mathrm{n}=68$ ), as well as among all data from 0-9 m integrated samples collected from 4 stns $(\mathrm{r}=$
0.77, $\mathrm{p}<0.001, \mathrm{n}=31$ ). When individual vertical profiles were considered, concentrations of viruses and prokaryotes were significantly correlated only in April $(\mathrm{r}=0.73, \mathrm{p}=0.027, \mathrm{n}=9)$, July $(\mathrm{r}=0.67, \mathrm{p}=0.050, \mathrm{n}=$ $9)$, and November ( $\mathrm{r}=0.94, \mathrm{p}<0.001, \mathrm{n}=8)$. There were no other significant correlations among concentrations of viruses and prokaryotes, VPR, FVIC, temperature, dissolved oxygen, or chl a concentrations, regardless of whether the entire data set or data for any individual vertical profile were considered. How-
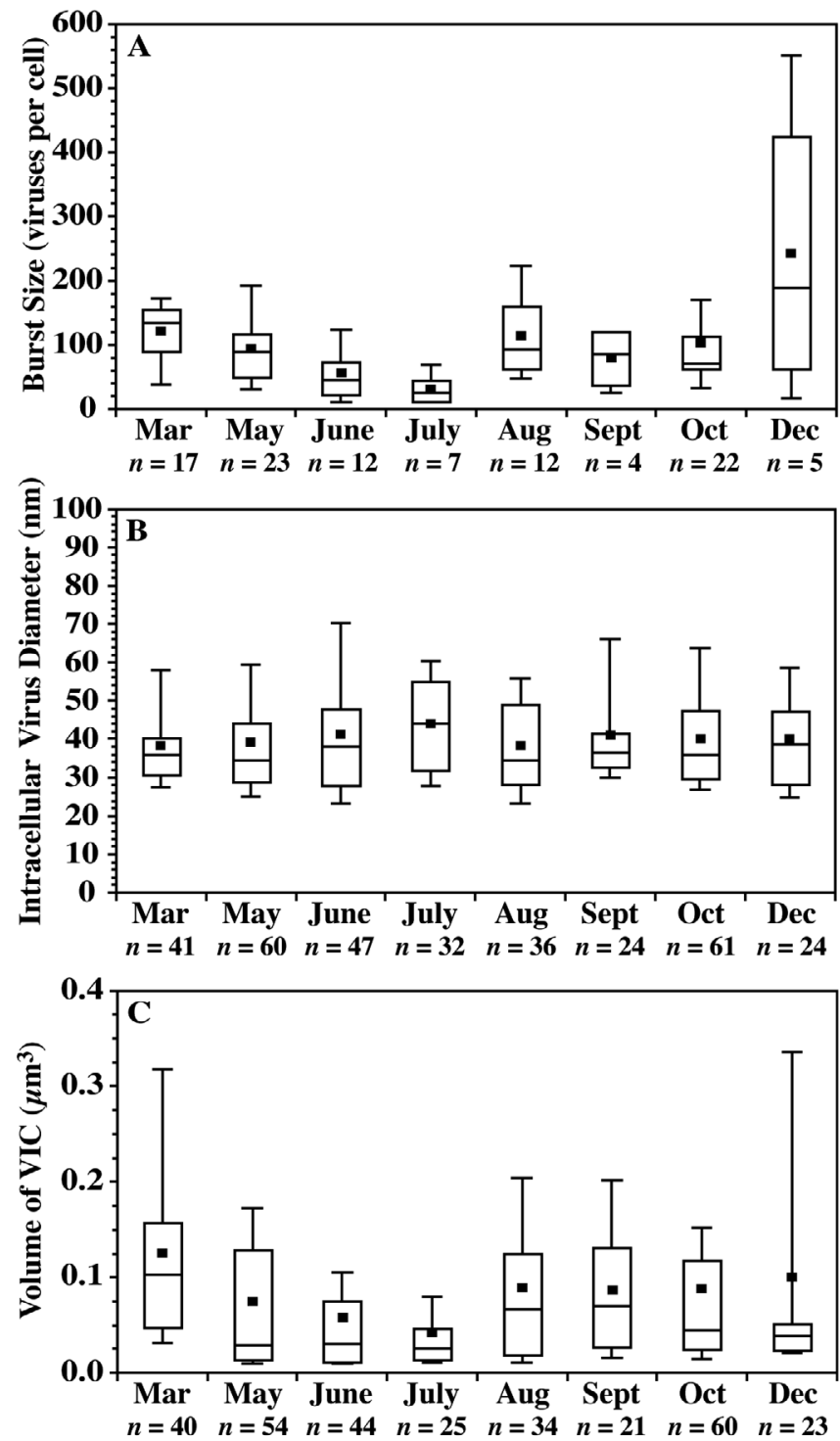

Fig. 5. Box and whisker plots of (A) burst size, (B) intracellular virus diameter, and $(\mathrm{C})$ volume of visibly infected cells (VIC) for each month from depth profiles at Stn 6 . Top, middle, and bottom lines of each box correspond to 75th, 50th (median), and 25th percentiles respectively. Whiskers extending from the top and bottom of each box correspond to 90th and 10th percentile, respectively. Solid squares within each box correspond to means 

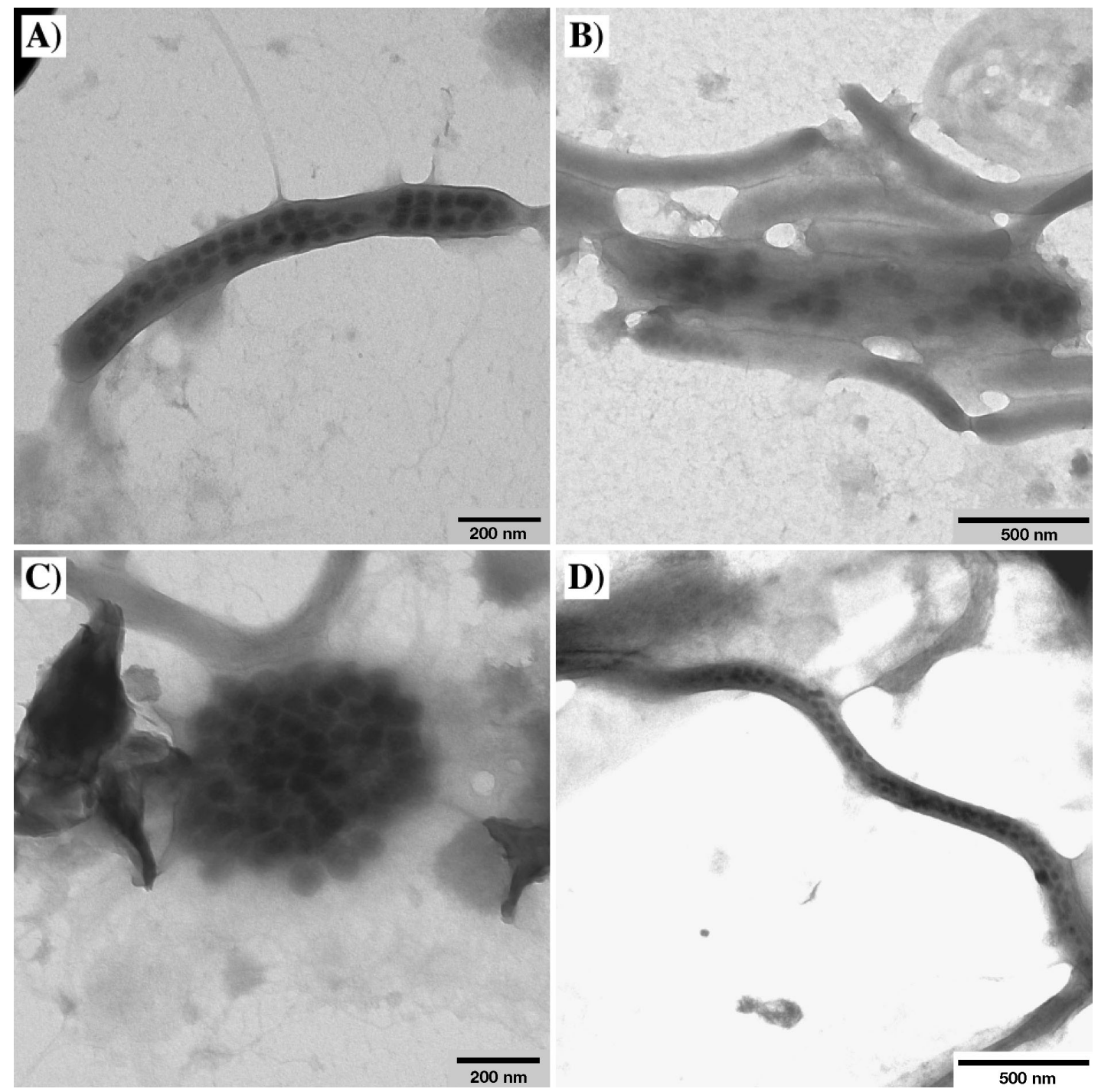

Fig. 6. Transmission electron micrographs of VIC representing 4 cell morphotypes observed throughout the study period. Micrographs show examples of (A) an infected thin rod, (B) an infected fat rod (center) compared to an infected thin rod (below) and uninfected thin rods (above), (C) an infected coccoid cell, and (D) a segment of an infected spirilla cell

ever, when analyzing monthly water column averages, FVIC was positively correlated with VPR at Stn $6(\mathrm{r}=$ 0.93, $\mathrm{p}=0.007, \mathrm{n}=6$ ) and in all 0-9 m integrated samples $(\mathrm{r}=0.74, \mathrm{p}=0.002, \mathrm{n}=15)$.

Pearson correlation analyses were also used to investigate temporal relationships among the monthly water column averages of burst size, diameter of intracellular viruses, and volume of VIC. The diameter of intracellular viruses was negatively correlated with the volume of VIC $(r=-0.81, p=0.015, n=8)$, but there were no significant correlations between either of these variables and burst size. December was the only month sampled in which there was no stratification of the water column, and burst size was exceptionally variable in this month. Therefore, these correlation analy- ses were repeated using only data from months in which Mono Lake was stratified. When data from December was excluded, there was little change in the correlation between the diameter of intracellular viruses and the volume of VIC $(\mathrm{r}=-0.83, \mathrm{p}=0.021, \mathrm{n}=$ 7 ), but burst size was now negatively correlated with the diameter of intracellular viruses $(\mathrm{r}=-0.96, \mathrm{p}<$ $0.001, \mathrm{n}=7$ ) and positively correlated with the volume of VIC $(r=0.90, p=0.006, n=7)$.

\section{Cell morphotypes}

The 4 observed morphotypes of cells (thin rods, fat rods, cocci, and spirilla [Fig. 6]) were subjectively 
determined based on observations during transmission electron microscopy (TEM) examination, which may have lead to some overlap among groups. To evaluate the ability of subjective determinations to resolve groups, the dimensions of all infected cells $(n=303)$ as determined by image analysis of micrographs (micrographs were not routinely taken of uninfected cells) were used to create post hoc definitions of morphotypes that minimized overlap. Cocci were defined as having a length:width ratio between 1 and 2, fat rods were defined as having a length:width ratio between 2 and 5 or having a width greater than $200 \mathrm{~nm}$, and thin rods were defined as having a length:width ratio greater than 5 and a width less than $200 \mathrm{~nm}$. Within these objective post-hoc definitions there was a $3 \%$ overlap between subjectively defined cocci and fat rods, and a $7 \%$ overlap between subjectively defined fat rods and thin rods. The low percentage overlap between these morphotypes suggested that analysis and discussion of them as separate populations was warranted.

Thin rods, fat rods, and cocci were observed at all depths each month but spirilla were only observed in the anoxic zone. The spirilla occurred at very low concentrations, and only 11 visibly infected spirilla were observed throughout the study period. They were grouped together with the thin rods for FVIC and FMVL calculations because they were initially not counted as a separate group in TEM grid analyses. In general, cocci were the least abundant morphotype, fat rods were the second most abundant, and thin rods were always the most abundant morphotype each month (Table 2). The abundance of each morphotype was not significantly different between the oxic and anoxic zones with the exception of March, when fat rods and cocci were significantly more abundant in the anoxic zone ( $t$-tests, $\mathrm{p}=0.031$ and $\mathrm{p}=0.004$, respectively) and thin rods were significantly more abundant in the oxic zone ( $t$-test, $\mathrm{p}=0.007$ ).

The FVIC of each morphotype was highly variable in vertical profiles, resulting in high standard deviations for the monthly water column averages and making it difficult to discern morphotype-specific patterns in infection (Table 2). However, the water-column average FVIC was highest in July for each morphotype. Cocci were the dominant infected cell morphotype in July, with their FVIC reaching as high as $13 \%$ at $20 \mathrm{~m}$. These infection rates resulted in the highest estimated FMVL for all morphotypes occurring in July, including an average FMVL of $63 \%$ (range 0 to $200 \%$ ) for cocci (Table 2). There were no significant differences in FVIC between the oxic and anoxic zones of the water column for morphotypes, except in June when FVIC of thin rods and fat rods were significantly higher in the oxic zone $(t$-tests, $p=0.035$ and $p=0.037$, respectively).

The seasonal trends in burst size, diameter of intracellular viruses, and volume of VIC are potentially influenced by variability in the relative abundance of each cell morphotype. Unfortunately, there was an insufficient abundance of each morphotype to determine these trends among individual months. However, average values for each morphotype abundance were determined from all data from Stn 6 over the entire study period, and separately for the oxic and anoxic zones.

There were no significant differences in burst size among morphotypes for all data, or for the oxic and anoxic zones (Fig. 7A). When individual morphotypes were considered, thin rods had larger burst sizes in the anoxic zone than in the oxic zone ( $t$-test, $\mathrm{p}=0.035)$, but there was no significant difference in burst size between the oxic and anoxic zones for fat rods or cocci. Because the burst size of spirilla could only be determined for 1 cell throughout the study period, no statistical comparisons were made for this morphotype.

The diameters of viruses within visibly infected thin rods were significantly smaller than the diameters of viruses within visibly infected fat rods and cocci for all data, as well as for data from the oxic and anoxic zones considered separately (ANOVAs, $\mathrm{p}<0.001$ for all; Fig. 7b). There was no significant difference between

Table 2. Percentages (water column mean $\pm \mathrm{SD}$ ) of all cells belonging to each of 3 major morphotypes (thin rods, fat rods, and Cocci), and FVIC and estimated FVML for each morphotype in Mono Lake at Stn 6

\begin{tabular}{|c|c|c|c|c|c|c|c|c|c|}
\hline \multirow[t]{2}{*}{ Month } & \multicolumn{3}{|c|}{ Cells (\%) } & \multicolumn{3}{|c|}{ FVIC (\%) } & \multicolumn{3}{|c|}{ FMVL (\%) } \\
\hline & Thin rods & Fat rods & Cocci & Thin rods & Fat rods & Cocci & Thin rods & Fat rods & Cocci \\
\hline Mar & $68.1 \pm 10.5$ & $25.9 \pm 6.9$ & $12.4 \pm 4.3$ & $0.3 \pm 0.3$ & $1.3 \pm 2.2$ & $1.2 \pm 1.4$ & $2.3 \pm 2.2$ & $14.1 \pm 28.2$ & $10.6 \pm 13.9$ \\
\hline May & $59.8 \pm 13.7$ & $22.3 \pm 3.8$ & $18.0 \pm 14.4$ & $0.9 \pm 0.7$ & $1.1 \pm 1.0$ & $0.7 \pm 0.7$ & $7.3 \pm 5.7$ & $8.9 \pm 9.2$ & $5.2 \pm 6.1$ \\
\hline Jun & $60.9 \pm 6.8$ & $30.6 \pm 5.9$ & $8.5 \pm 2.1$ & $0.6 \pm 0.3$ & $0.9 \pm 1.2$ & $0.3 \pm 0.8$ & $4.3 \pm 2.6$ & $7.4 \pm 10.9$ & $2.2 \pm 6.6$ \\
\hline Jul & $53.3 \pm 11.7$ & $31.1 \pm 7.3$ & $15.6 \pm 7.1$ & $1.1 \pm 0.8$ & $2.0 \pm 1.7$ & $4.6 \pm 4.5$ & $9.5 \pm 7.5$ & $19.1 \pm 19.4$ & $62.7 \pm 70.1$ \\
\hline Aug & $44.0 \pm 8.0$ & $36.8 \pm 4.1$ & $19.2 \pm 7.8$ & $0.6 \pm 0.5$ & $0.5 \pm 0.4$ & $0.8 \pm 1.4$ & $4.8 \pm 3.8$ & $3.6 \pm 3.4$ & $7.2 \pm 13.6$ \\
\hline Sep & $51.8 \pm 6.1$ & $32.8 \pm 4.9$ & $15.4 \pm 2.4$ & $0.6 \pm 0.2$ & $0.5 \pm 0.5$ & $0.1 \pm 0.3$ & $4.1 \pm 1.5$ & $4.2 \pm 3.5$ & $0.8 \pm 2.0$ \\
\hline Oct & $43.2 \pm 12.4$ & $30.4 \pm 4.8$ & $26.3 \pm 14.5$ & $0.8 \pm 0.7$ & $0.8 \pm 1.0$ & $0.2 \pm 0.4$ & $6.1 \pm 5.5$ & $7.2 \pm 9.4$ & $1.4 \pm 2.7$ \\
\hline Dec & $58.8 \pm 8.8$ & $19.0 \pm 2.3$ & $22.2 \pm 8.3$ & $0.4 \pm 0.3$ & $1.2 \pm 0.6$ & $0.3 \pm 0.5$ & $2.7 \pm 2.4$ & $9.4 \pm 5.2$ & $2.7 \pm 4.0$ \\
\hline
\end{tabular}



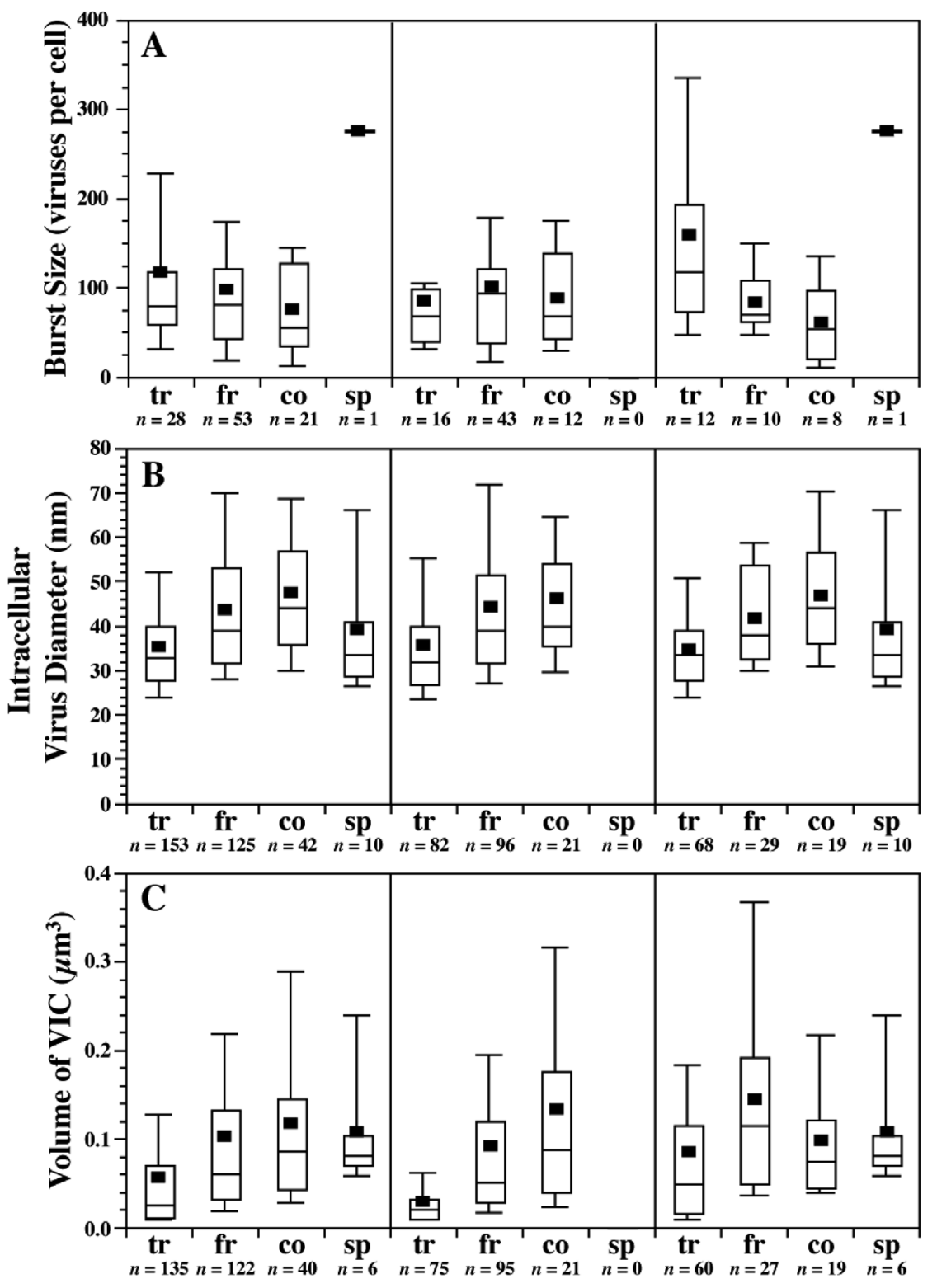

Water Column

Oxic

Anoxic

Fig. 7. Box and whisker plots of (A) burst size, (B) intracellular virus diameter, and (C) volume of VIC for each cell morphotype in the entire water column and in oxic and anoxic zones. Box plots include cells from all depth profiles at Stn 6 throughout the study period. Refer to Fig. 5 for a description of box and whisker plot construction; tr: thin rods; fr: fat rods, co: cocci; sp: spirilla

for data from the oxic zone only (ANOVAs, $p<0.001$ for all); there were no other significant differences among morphotypes (Fig. 7C). When individual morphotypes were considered, the volumes of thin rods were significantly greater in the anoxic than the oxic zone ( $t$-test, $\mathrm{p}<0.001)$. This difference was due to thin rods in the anoxic zone being significantly longer ( $t$-test, $\mathrm{p}<0.001)$, but not significantly wider, than thin rods in the oxic zone. There were no significant differences in cell volumes between the oxic and anoxic zones for fat rods or cocci, and spirilla were not found in the oxic zone.

\section{DISCUSSION}

\section{Temporal dynamics of prokaryotes and viruses}

A previous investigation of viruses and prokaryotes in Mono Lake (Jiang et al. 2004) found concentrations similar to those reported here, but the concentrations were not significantly correlated. The correlation between prokaryotes and viruses observed in this study was probably due to more extensive sampling, which captured a greater range of variability. The concentrations of prokaryotes and viruses were highest throughout the water column during spring, and the high concentrations persisted for up to $1 \mathrm{mo}$ after the decline of phytoplankton biomass in the mixolimnion that results from intense grazing by Artemia monica (Jellison \& Melack 1988). While concentrations of prokaryotes and viruses did decline by July, their abundance was always high relative to freshwater and seawater environ-

the diameters of viruses within fat rods and cocci, and no significant difference between those in spirilla and any other morphotype. For individual morphotypes, there was no significant difference in the diameters of intracellular viruses between the oxic and anoxic zones. Spirilla were not found in the oxic zone, so no statistical comparisons were made.

Cell volumes of thin rods were significantly less than cell volumes of fat rods and cocci for all data, and ments (Wommack \& Colwell 2000). Prokaryotes are likely sustained through the summer by residual DOM produced by phytoplankton during the bloom and its decline, which results from direct exudation, grazing, and perhaps viral lysis. Following the peak of the bloom, prokaryotes would have also benefited from nutrients remineralized by $A$. monica as well as from decreased competition with phytoplankton for those nutrients. The continued sustenance of prokaryotic 
growth throughout the year would also indirectly support the continued presence of viruses in excess of $10^{11} \mathrm{l}^{-1}$.

An increase in concentrations of prokaryotes and viruses in November coincided with the onset of holomixis in Mono Lake. The growth of prokaryotes may have been stimulated by organic matter produced in the autumn bloom that was apparent in the previous month, along with high concentrations of ammonia in the monimolimnion mixed throughout the water column (Jellison et al. 1993). Increased concentrations of prokaryotes and viruses in November were not sustained through December, which may have been a result of decreased substrate availability, lower temperatures, or a combination of both (Pomeroy \& Deibel 1986, Wiebe et al. 1993, Kirchman \& Rich 1997).

\section{Temporal dynamics of FVIC}

FVIC had similar temporal dynamics to concentrations of viruses and prokaryotes, except that the maximum FVIC occurred in July, the month that concentrations of viruses and prokaryotes declined. A temporal lag of 1 to $2 \mathrm{wk}$ between peaks in bacterial concentration and FVIC has previously been reported for a mesotrophic, freshwater lake (Hennes \& Simon 1995). While the average FVIC of thin rods and fat rods increased slightly in July, the peak in total FVIC was primarily a result of an extremely high proportion of FVIC of cocci, which reached as high as $13 \%$. Overall, water column averages of FVIC and VPR were positively correlated, but one can only speculate about the nature of any possible causal link. For example, higher VPR may have caused higher infection rates due to increased contact rates between viruses and their hosts. Conversely, higher FVIC could have resulted in higher VPR due to the death of cells via viral lysis and the concomitant production of viruses. Since FVIC appears to increase with prokaryotic production and growth rate (Steward et al. 1996), inclusion of these measurements in future investigations may provide additional insights into the causes of temporal variability in FVIC.

Despite concentrations of prokaryotes and viruses that are all substantially higher than in most other aquatic environments (Wommack \& Colwell 2000), the average FVIC of $0.8 \pm 0.7 \%$ in this study was at the low end reported for other aquatic environments (as summarized in Binder 1999). As a result, the estimated contribution of viruses to the mortality of prokaryotes in Mono Lake was also relatively low (6.3\% on average). Despite the low overall community average, viruses did appear to have a significant, but transient and localized, impact on one particular morphotype, caus- ing from 0 to $200 \%$ (average $63 \%$ ) of the mortality of cocci in July, depending on the depth. Mortality in excess of $100 \%$ indicated that viral mortality was temporarily in excess of the cell production rate for that population.

It is possible that episodes of high infection rates occurred more frequently in the lake, but were shortlived and thus poorly resolved by our monthly sampling. We note also that the model used to derive FMVL from FVIC required several assumptions about the bacteriophage infection cycle, the parameters of which are still poorly constrained for populations in the environment (Binder 1999). Therefore, although the FVIC data were comparable to other studies, the estimates of viral mortality had considerable uncertainty. Grazing by protists is one likely fate of the prokaryote production that is not accounted for by viral lysis. Diverse protozoa exist in Mono Lake (L. A. Davidson pers. comm.), but at present there are no data on their abundance or their rates of grazing on prokaryotes that could be used to constrain our estimates of viral mortality.

The high concentrations of prokaryotes and viruses in Mono Lake result in specific contact rates that are up to an order of magnitude higher than those reported for other aquatic environments (Weinbauer \& Hofle 1998a,b, Wilhelm et al. 1998, Fischer \& Velimirov 2002). In some reports, where contact rates were on the order of 100 to $250 \mathrm{cell}^{-1} \mathrm{~d}^{-1}$, viruses were estimated to be the major source of mortality of prokaryotes (Weinbauer \& Hofle 1998a, Fischer \& Velimirov 2002). However, as in Mono Lake, high concentrations of viruses and prokaryotes in hypersaline evaporator ponds did not result in high FVIC (Guixa-Boixareu et al. 1996), which may reflect the nature of viral infections in high salinity aquatic environments.

That the FVIC in Mono Lake remains low in spite of extraordinarily high contact rates suggests that very few contacts result in productive infections. This could occur if the microbial community is more diverse than other environments, or if a large proportion of each population is resistant to co-occurring viruses. While the diversity of viruses (Jiang et al. 2004) and prokaryotes (Hollibaugh et al. 2001, Humayoun et al. 2003) does appear to be high in Mono Lake, the resolution of the methods used among studies does not permit reliable quantitative comparisons to other environments. As for the second possibility, it is highly likely that there are significant sub-populations of prokaryotes resistant to co-occurring viruses. Resistance develops readily in bacterial populations exposed to a lytic bacteriophage, which can result in the stable coexistence of host and virus at high abundance (Levin et al. 1977). This phenomenon has been repeatedly demonstrated in theoretical and experimental studies (Levin et al. 
1977, Bohannan \& Lenski 2000, Middelboe 2000), and has been demonstrated in field populations of cyanobacteria (Waterbury \& Valois 1993).

\section{Spatial patterns of prokaryotes, viruses, and FVIC}

Significant differences in concentrations of prokaryotes and viruses have been observed between the layers of vertically stratified monomictic (Weinbauer \& Hofle 1998a) and meromictic (Bettarel et al. 2003) lakes, including Mono Lake (Jiang et al. 2004). Previous studies have also found peaks in concentrations of prokaryotes and viruses at transition zones in stratified aquatic environments, including peaks in the thermocline (Weinbauer et al. 1995) and oxycline (Taylor et al. 2003) of oceanic environments, and in the metalimnion of stratified lakes that have either an oxic (Bettarel et al. 2003) or an anoxic (Weinbauer \& Hofle 1998a) hypolimnion. In the latter 2 reports, significant differences in FVIC were also found between the epi- and hypolimnion. In contrast to these previous studies, no significant differences in virus or prokaryote concentrations, and only minor differences in FVIC, were detected between the oxic and anoxic zones of Mono Lake in this study. Likewise, no maxima or minima in these properties were discernible at the oxycline in any depth profile.

Horizontal variability in concentrations of prokaryotes and viruses and in FVIC appeared to be due to transient patchiness. There were no systematic differences among stations despite differences in their depth and proximity to shore, which was consistent with a previous study at Mono Lake that found no significant differences in concentrations of prokaryotes and viruses among 4 stations on 3 separate dates (Jiang et al. 2004).

\section{Burst size, virus diameter, and cell volume}

ANOVA indicated that there were few significant month-to-month differences in burst size, intracellular virus diameter, or infected cell volume, but this test was not designed for discerning temporal trends. Significant correlations among these 3 properties suggested that observed temporal trends were not due to random variability, but reflected real changes in the community over time. There was an overall trend for larger viruses to infect smaller cells from March to July, followed by an increase in burst sizes as smaller viruses infected larger cells in August.

Since these 3 properties also varied significantly among morphotypes, the observed temporal variability may have been due to changes in the proportion of infected cells of each morphotype. For example, the significant decrease in burst size in July could have been due to the very high FVIC of coccoid cells, since this morphotype had a significantly lower average burst size. However, cocci were still a small component of the total abundance of cells in July, and their influence on average burst size was not sufficient to explain the observed temporal variability in burst size, diameter of intracellular viruses, or volume of VIC. The temporal patterns in these parameters thus appeared to reflect community-wide shifts in phage-host systems over time.

The correlations observed in this study confirmed previous findings that burst size increases with cell size (Weinbauer \& Peduzzi 1994, Hennes \& Simon 1995, Weinbauer \& Hofle 1998b) and decreases with larger infecting viruses (Weinbauer \& Peduzzi 1994, Hennes \& Simon 1995). Some inter-correlation among these variables is to be expected because of the restrictive criterion that only full cells contribute to the calculation of burst size. While cell volume can vary as a result of physiological status, capsid diameter is a fixed characteristic for a given virus type. Therefore, the significant correlation between burst size and intracellular viral diameter suggests that temporal variability in burst size in Mono Lake must be due, at least in part, to changes in the community composition of actively replicating viruses.

There were no significant differences in burst size or intracellular virus diameters between the oxic and anoxic zones of Mono Lake, which is consistent with observations in some other stratified aquatic environments (Choi et al. 2003, Bettarel et al. 2004). However, these results were in contrast to other studies in which burst sizes were found to be significantly larger in anoxic bottom waters relative to overlying oxic waters (Weinbauer \& Hofle 1998b, Weinbauer et al. 2003). In the eutrophic Lake Plusssee, a larger average burst size in anoxic waters was attributed to larger cell volumes (Weinbauer \& Hofle 1998b). In this study, average volumes of infected cells in the anoxic zone were also significantly greater relative to the oxic zone, but the difference was not sufficiently large to result in significantly larger burst sizes.

\section{CONCLUSIONS}

Mono Lake appears to differ from other stratified aquatic systems in that it has relatively uniform vertical distributions of viral and bacterial abundance and incidence of viral infection. This homogeneity is remarkable given the dramatic differences between the oxic and anoxic waters of Mono Lake in terms of temperature, concentrations of oxygen, sulfide, and 
ammonia, phytoplankton biomass, and even microbial community composition. The data suggested that some aspect of seasonal forcing is the primary source of variability in viral infection rates, and that this similarly influences the infection processes in microbial communities in the 2 very different habitats of the oxic and anoxic zones. While temporal trends in FVIC and burst size appeared to be linked to seasonal cycles of physical and biological processes in the lake, data from additional years will be required to determine if these patterns are replicable. Mono Lake showed similarities to hypersaline salt ponds in having very high viral and bacterial concentrations, but only moderate levels of infection. The estimated impact of viruses as a source of mortality for prokaryotes varied significantly, but appeared to be low overall, meaning that other important sources of mortality in the lake remain to be identified and quantified. The very high estimated contact rates between viruses and prokaryotes suggest that, even if viruses contribute little to total mortality, they are likely to exert a strong influence on clonal diversity of prokaryotes in this unusual environment by selecting for virus-resistant strains.

Acknowledgements. We thank Sandra Roll and Kimberly Rose for sample collection and for providing logistical support at the Sierra Nevada Aquatic Research Laboratory. We also thank Tina Carvalho of the University of Hawaii Biological Electron Microscope Facility for her assistance with TEM, and Mandy Han of the University of California (Irvine) for her assistance with counts of prokaryotes and viruses. This research was supported by the National Science Foundation under grants DEB01-29174, DEB01-30528, and DEB01-29160 to G.F.S., S.C.J., and R.J., respectively. This is SOEST contribution 6671 .

\section{LITERATURE CITED}

Bettarel Y, Amblard C, Carrias JF, Sargos D, Garabétian F, Lavandier P (2003) Viral lysis, flagellate grazing potential, and bacterial production in Lake Pavin. Microb Ecol 45: 119-127

Bettarel Y, Sime-Ngando T, Amblard C, Dolan JR (2004) Viral activity in two contrasting lake ecosystems. Appl Environ Microbiol 70:2941-2951

Binder B (1999) Reconsidering the relationship between virally induced bacterial mortality and frequency of infected cells. Aquat Microb Ecol 18:207-215

Bohannan BJM, Lenski RE (2000) Linking genetic change to community evolution: insights from studies of bacteria and bacteriophage. Ecol Lett 3:362-377

Bratbak G, Heldal M, Norland S, Thingstad TF (1990) Viruses as partners in spring bloom microbial trophodynamics. Appl Environ Microbiol 56:1400-1405

Choi DH, Hwang CY, Cho BC (2003) Comparison of virusand bacterivory-induced bacterial mortality in the eutrophic Masan Bay, Korea. Aquat Microb Ecol 30: $117-125$

Fischer UR, Velimirov B (2002) High control of bacterial production by viruses in a eutrophic oxbow lake. Aquat Microb Ecol 27:1-12
Fuhrman JA, Suttle CA (1993) Viruses in marine planktonic systems. Oceanography 6:51-63

Guixa-Boixareu N, Calderon-Paz JI, Heldal M, Bratbak G, Pedros-Alio C (1996) Viral lysis and bacterivory as prokaryotic loss factors along a salinity gradient. Aquat Microb Ecol 11:215-227

Hennes KP, Simon M (1995) Significance of bacteriophages for controlling bacterioplankton growth in a mesotrophic lake. Appl Environ Microbiol 61:333-340

Hollibaugh JT, Wong PS, Bano N, Pak SK, Prager EM, Orrego C (2001) Stratification of microbial assemblages in Mono Lake, California, and response to a mixing event. Hydrobiologia 466:45-60

Humayoun SB, Bano N, Hollibaugh JT (2003) Depth distribution of microbial diversity in Mono Lake, a meromictic soda lake in California. Appl Environ Microbiol 69: 1030-1032

Jellison R, Melack JM (1988) Photosynthetic activity of phytoplankton and its relation to environmental factors in hypersaline Mono Lake, California. Hydrobiologia 158: $69-88$

Jellison R, Melack JM (1993a) Meromixis in hypersaline Mono Lake, California. 1. Stratification and vertical mixing during the onset, persistence, and breakdown of meromixis. Limnol Oceanogr 38:1008-1019

Jellison R, Melack JM (1993b) Algal photosynthetic activity and its response to meromixis in hypersaline Mono Lake, California. Limnol Oceanogr 38:818-837

Jellison R, Melack JM (2001) Nitrogen limitation and particulate elemental ratios of seston in hypersaline Mono Lake, California, USA. Hydrobiologia 466:1-12

Jellison R, Miller LG, Melack JM, Dana GL (1993) Meromixis in hypersaline Mono Lake, California 2. Nitrogen fluxes. Limnol Oceanogr 38:1020-1039

Jellison R, Romero J, Melack JM (1998) The onset of meromixis during restoration of Mono Lake, California: unintended consequences of reducing water diversions. Limnol Oceanogr 43:706-711

Jiang SC, Steward GF, Jellison R, Chu W, Choi S (2004) Abundance, distribution and diversity of viruses in alkaline, hypersaline, Mono Lake, California. Microb Ecol 47: 9-17

Kirchman DL, Rich JH (1997) Regulation of bacterial growth rates by dissolved organic carbon and temperature in the equatorial Pacific Ocean. Microb Ecol 33:11-20

Laybourn-Parry J, Hofer JS, Sommaruga R (2001) Viruses in the plankton of freshwater and saline Antarctic lakes. Freshw Biol 46:1279-1287

Lenz PH, Cooper SD, Melack JM, Winkler DW (1986) Spatial and temporal distribution patterns of three trophic levels in a saline lake. J Plankton Res 8:1051-1064

Levin BR, Stewart FM, Chao L (1977) Resource-limited growth, competition, and predation: a model and experimental studies with bacteria and bacteriophage. Am Nat 111:3-24

Melack JM, Jellison R (1998) Limnological conditions in Mono Lake: contrasting monomixis and meromixis in the 1990s. Hydrobiologia 384:21-39

Middelboe M (2000) Bacterial growth rate and marine virushost dynamics. Microb Ecol 40:114-124

Middelboe M, Jorgensen NOG, Kroer N (1996) Effects of viruses on nutrient turnover and growth efficiency of noninfected marine bacterioplankton. Appl Environ Microbiol 62:1991-1997

Murray AG, Eldridge PM (1994) Marine viral ecologyincorporation of bacteriophage into the microbial planktonic food web paradigm. J Plankton Res 16:627-641 
Murray AG, Jackson GS (1992) Viral dynamics: a model of the effects of size, shape, motion and abundance of singlecelled planktonic organisms and other particles. Mar Ecol Prog Ser 89:103-116

Noble RT, Fuhrman JA (1998) Use of SYBR Green I for rapid epifluorescence counts of marine viruses and bacteria. Aquat Microb Ecol 14:113-118

Paul JH, Rose JB, Jiang SC, Kellogg CA, Dickson L (1993) Distribution of viral abundance in the reef environment of Key Largo, Florida. Appl Environ Microbiol 59: $718-724$

Pomeroy LR, Deibel D (1986) Temperature regulation of bacterial activity during the spring bloom in Newfoundland coastal waters. Science 233:359-361

Proctor LM, Okubo A, Fuhrman JA (1993) Calibrating estimates of phage-induced mortality in marine bacteria: ultrastructural studies of marine bacteriophage development from one-step growth experiments. Microb Ecol 25: 161-182

Rodriguez F, Fernandez E, Head RN, Harbour DS, Bratbak G, Heldal M, Harris RP (2000) Temporal variability of viruses, bacteria, phytoplankton and zooplankton in the western English Channel off Plymouth. J Mar Biol Assoc UK 80: 575-586

Roesler CS, Culbertson CW, Etheridge SM, Goericke R, Kiene RP, Miller LG, Oremland RS (2002) Distribution, production, and ecophysiology of Picocystis strain ML in Mono Lake, California. Limnol Oceanogr 47:440-452

Steward GF, Smith DC, Azam F (1996) Abundance and production of bacteria and viruses in the Bering and Chukchi Seas. Mar Ecol Prog Ser 131:287-300

Taylor GT, Hein C, Iabichella M (2003) Temporal variations in viral distributions in the anoxic Cariaco Basin. Aquat Microb Ecol 30:103-116

Walker KF, Williams WD, Hammer UT (1970) The Miller method for oxygen determination applied to saline lakes. Limnol Oceanogr 15:814-815

Editorial responsibility: Jed Fuhrman,

Los Angeles, California, USA
Waterbury JB, Valois FW (1993) Resistance to co-occurring phages enables marine Synechococcus communities to coexist with cyanophages abundant in seawater. Appl Environ Microbiol 59:3393-3399

Weinbauer MG, Hofle MG (1998a) Significance of viral lysis and flagellate grazing as factors controlling bacterioplankton production in a eutrophic lake. Appl Environ Microbiol 64:431-438

Weinbauer MG, Hofle MG (1998b) Size-specific mortality of lake bacterioplankton by natural virus communities. Aquat Microb Ecol 15:103-113

Weinbauer MG, Peduzzi P (1994) Frequency, size and distribution of bacteriophages in different marine bacterial morphotypes. Mar Ecol Prog Ser 108:11-20

Weinbauer MG, Fuks D, Peduzzi P (1993) Distribution of viruses and dissolved DNA along a coastal trophic gradient in the northern Adriatic Sea. Appl Environ Microbiol 59:4074-4082

Weinbauer MG, Fuks D, Puskaric S, Peduzzi P (1995) Diel, seasonal, and depth-related variability of viruses and dissolved DNA in the Northern Adriatic Sea. Microb Ecol 30: $25-41$

Weinbauer MG, Brettar I, Hofle MG (2003) Lysogeny and virus-induced mortality of bacterioplankton in surface, deep, and anoxic waters. Limnol Oceanogr 48:1457-1465

Wiebe WJ, Sheldon WM Jr, Pomeroy LR (1993) Evidence for an enhanced substrate requirement by marine mesophilic bacterial isolates at minimal growth temperatures. Microb Ecol 25:151-159

Wilcox RM, Fuhrman JA (1994) Bacterial viruses in coastal seawater: lytic rather than lysogenic production. Mar Ecol Prog Ser 114:35-45

Wilhelm SW, Weinbauer MG, Suttle CA, Jeffrey WH (1998) The role of sunlight in the removal and repair of viruses in the sea. Limnol Oceanogr 43:586-592

Wommack KE, Colwell RR (2000) Virioplankton: viruses in aquatic ecosystems. Microbiol Mol Biol Rev 64:69-114

Submitted: July 18, 2005; Accepted: September 12, 2005 Proofs received from author(s): November 29, 2005 